\title{
The Study between Accounting Information and Investment Effectiveness
}

\author{
Jing $\mathrm{Ma}^{1, \mathrm{a},{ }^{*}}$ \\ ${ }^{1}$ Beijing Jiaotong University, China \\ a13155832952@163.com \\ *Corresponding author
}

\begin{abstract}
Keywords: Investment effectiveness, State-owned enterprises, Non-state-owned enterprises,
\end{abstract} Accounting information quality

\begin{abstract}
From the perspective of the quality of accounting information, taking Chinese A-share listed companies in the stock market from 2014 to 2016 as a sample to study the influence of accounting information quality on over-investment and under-investment, and the performance of accounting information quality under different property rights. The results show that: the quality of accounting information can improve corporate investment efficiency, but the impact on under-invested companies is higher than that of over-invested companies; the quality of accounting information in state-owned enterprises has a higher impact on investment efficiency than non-state-owned enterprises. To a certain extent, it shows that it is greatly significant to formulate high-quality accounting standards.
\end{abstract}

\section{Introduction}

The MM theory confirms that under the strict assumption that the information is complete, there is no transaction cost, and the company's investment behavior is not affected by the selected financing method. However, there is no perfect capital market in the reality. Therefore, the asymmetry of information and the trade friction brought by moral hazard will cause the company's actual investment to deviate from optimal investment scale in different degrees, resulting in excessive investment or insufficient investment. The purpose of the company is to maximize its value. Whether it is over-investment or under-investment will have a negative impact on the company's profitability in the future, and hinder the healthy development of the economy.

The quality of accounting information is an important indicator for enterprises to transfer information to the outside world. The high accounting quality disclosed to a certain extent can ease the information asymmetry between the company and external investors, and can improve company investment efficiency. Therefore, the study of the impact of the quality of accounting information on investment efficiency can help people to further examine the economic consequences of accounting information quality, and it has strong theoretical and practical values.

There are two main contents of this paper: (1) How is the quality of accounting information affecting non-efficient investment forms? (2) Whether non-state-owned enterprises have a stronger incentive than state-owned enterprises to provide investors with high-quality accounting information.

\section{Literature review}

In the study of the factors affecting investment efficiency, the current literature mainly focuses on the impact of governance mechanisms on investment efficiency. Chen et al. found that government intervention reduced the investment efficiency of state-owned enterprises from the perspective of the ultimate controller of the company [1].

The economic consequences of accounting information quality are one of the hot issues in financial and accounting research. However, there are few empirical literatures that relate the quality of accounting information to investment efficiency. Bushman \& Smith believed that the quality of 
accounting information could help investors identify and differentiate through good investments and bad investments [2]. Merton pointed out that when a company's information disclosure failed to meet the requirements, investors would consider risk premium when valuing the company's stock, thereby increasing the company's financing costs [3]. Chen found that high-quality financial reports could effectively mitigate investment over-investment and improve investment efficiency [4].

From the above literatures, we can see that research on the impact of the quality of accounting information, foreign researches use more listed companies in capital markets of developed countries, and the articles about domestic direct research on the impact of financial report quality on investment efficiency are not comprehensive enough: Although the distinction between over-investment and under-investment has been made, there is no analysis of the impact of the quality of accounting information on inefficiencies and differences in the nature of property rights. In view of this, this article intends to take the sample of A-share listed companies in Shanghai and Shenzhen stock markets from 2014 to 2016 to analyze the influence of the quality of accounting information on the two different investment states and the differences in different equity.

\section{Theoretical analysis and hypothesis}

In the capital market, high-quality accounting information is an important basis for external investors to make decisions, because the market is imperfect and information is asymmetric.

Due to the different interests between shareholders and managers and the lack of supervision of managers by shareholders, managers have the incentive to maximize their own profits through investment, and these investments may be unprofitable for shareholders, therefore the result may cause excessive investment;

Second, capital providers may be aware that managers use the available resources to maximize the private benefits or the on-the-job consumption, so they will reduce the capital allocation to the company, which will lead to the company facing financing constraints and even bad credit rationing. Then they may give up positive net present value projects that can increase the company's value in order to reduce the proportion of external financing, resulting in insufficient investment. Since more managers are risk averse, the number of underinvested companies tends to be more than that of overinvested companies. Based on the above analysis, put forward hypothesis:

$\mathrm{H} 1$ : The improvement of the quality of accounting information can reduce inefficient investment, and it also has a higher impact on under-invested companies than over-investment companies.

It is generally believed that, compared to low-quality accounting information, high-quality accounting information is more conducive to the performance of its functions, thus it can effectively inhibit the company's non-efficiency investment. The degree of information asymmetry between the company and external investors are higher, the role of accounting pricing information and governance functions is more important. Considering that the financing constraints normally faced by non-state-owned enterprises are generally higher, we think in order to alleviate the financing difficulties suffered in the formal financial market, non-state-owned enterprises have a stronger incentive to provide investors with high-quality accounting information reducing the incidence of agent conflicts. Based on the analysis, putting forward the second hypothesis:

H2: The impact of the quality of accounting information on investment efficiency in non-state-owned enterprises is higher than that of state-owned enterprises

\section{Study}

\subsection{Data sources and sample selection}

This article takes a sample of A-share listed companies from 2014 to 2016 in Shanghai and Shenzhen. Because the need of using data for the first-phase lag and operating income difference, the relevant data calculation period is from 2012 to 2016. We screened the sample according to the following principles: (1) Excluding samples from the financial and insurance industries; (2) Excluding data 
missing for 5 years and finally obtaining 8600 observations. In order to reduce the impact of outliers, this paper performs the $1 \%$ quantile Winsor processing on the main continuous variables. The listed company's financial data and industry category data used in this article are all derived from CSMAR database.

\subsection{Measurement of accounting information quality}

This method to measure the quality of accounting information is using absolute level of earnings management of financial reporting. This article selects the modified Jones model to measure accounting information.

$$
\mathrm{TA}_{\mathrm{i}, \mathrm{t}} / \mathrm{A}_{\mathrm{i}, \mathrm{t}-1}=\alpha_{0}\left(1 / \mathrm{A}_{\mathrm{i}, \mathrm{t}-1}\right)+\alpha_{2}\left(\triangle \mathrm{REV}_{\mathrm{i}, \mathrm{t}}-\triangle \mathrm{REC}_{\mathrm{i}, \mathrm{t}}\right) / \mathrm{A}_{\mathrm{i}, \mathrm{t}-1}+\alpha_{3}\left(\mathrm{PPE}_{\mathrm{i}, \mathrm{t}} / \mathrm{A}_{\mathrm{i}, \mathrm{t}-1}\right)+\xi_{\mathrm{i}, \mathrm{t}} .
$$

Among them, TA is the total accrued profit; $\mathrm{Ai}$ is the period ending total assets; $\triangle \mathrm{REV}$ is the company's t period at the end of operating income - $t-1$ period of the end of operating income; $\triangle \mathrm{REC}$ is the company i year t period ending balance of accounts receivable Amount - net ending amount of accounts receivable for period t-1; PPE is the net fixed assets at the end of period t of company $\mathrm{i}$; model's estimated residual represents the company's manipulative accruals. We use the EM to represent the absolute value of the residual error obtained by regression of the model (1). The greater the EM, the higher the company's earnings management, the lower the quality of accounting information.

\subsection{Measurement of inefficient investment}

This paper uses the Richardson model to measure the degree of over-investment and under-investment, which has been widely used in China. The model first estimates the company's normal investment level, and then uses the difference between the actual investment level of the company and the estimated investment level to indicate that the investment is insufficient (the residual is less than 0 , the residual is taken as an absolute value, represented by $U$ ) and the excessive investment (the residual is greater than 0 , denoted by $\mathrm{O}$ ), and inefficient investment |UI| indicates that the greater the regression residual, the lower the company's investment efficiency.

$$
\mathrm{INV}_{\mathrm{i}, \mathrm{t}}=\mathrm{y}_{0}+\mathrm{y}_{1} \text { growth }_{\mathrm{i}, \mathrm{t}-1}+\mathrm{y}_{2} \operatorname{lev}_{\mathrm{i}, \mathrm{t}-1}+\mathrm{y}_{3} \mathrm{fcf}_{\mathrm{i}, \mathrm{t}-1}+\mathrm{y}_{4} \operatorname{size}_{\mathrm{i}, \mathrm{t}-1}+\mathrm{y}_{5} \operatorname{return}_{\mathrm{i}, \mathrm{t}-1}+\mathrm{y}_{6} \mathrm{INV}_{\mathrm{i}, \mathrm{t}-1}+\mathrm{y}_{7} \text { Ind }+\mathrm{y}_{8} \mathrm{year}+\varepsilon_{\mathrm{i}, \mathrm{t}} \text {. }
$$

Among them, INV is the company's new investment increase in year t; Growth is the company's t year annual operating income growth rate; Lev is the company's t year asset liability ratio; Fcf is the free cash flow of company I in year t-1; Size is the size of company i in year t; Return represents company I per earnings; Ind and Year are dummy variables reflecting industry and annual effects, $\varepsilon_{\mathrm{i}, \mathrm{t}}$ is the error term.

\subsection{Model setting and variable description}

In order to examine the impact of the quality of accounting information on the company's investment efficiency and the influence under different ownership rights, the test model constructed in this paper is as follows:

$$
\mathrm{O}_{\mathrm{i}, \mathrm{t}}\left(\mathrm{U}_{\mathrm{i}, \mathrm{t}}\right)=\mathrm{r}_{0}+\mathrm{r}_{1} \mathrm{EM}_{\mathrm{i}, \mathrm{t}-1}+\mathrm{r}_{2} \mathrm{sar}_{\mathrm{i}, \mathrm{t}-1}+\mathrm{r}_{3} \text { roa }_{\mathrm{i}, \mathrm{t}-1}+\mathrm{r}_{4} \text { cont }_{\mathrm{i}, \mathrm{t}-1}+\mathrm{r}_{5} \mathrm{sh}_{\mathrm{i}, \mathrm{t}-1}+\mathrm{r}_{6} \text { Ind }+\mathrm{r}_{7} \text { year }+\varepsilon_{\mathrm{i}, \mathrm{t}} \text {. }
$$

Sar indicates the company's asset turnover; Roa indicates the company's total return on assets; Cont expresses the nature of property rights, with 1 being a state-owned company and 0 being non-state-owned; The explanatory variable is $\mathrm{O}(\mathrm{U})$, which is the absolute value of the model 1 residual, and represents non-efficiency investment; The explanatory variable EM is the absolute value of the model 2 residual and represents the quality of accounting information; Control variables include: (1)Asset turnover rate (sar). The specific calculation method is to use the current business income of the company divided by the average total assets;(2)The total return on assets (roa). The specific calculation method is to use the company's current net profit divided by the average total assets;(3)Property variables. This paper sets up dummy variables to distinguish between state-owned 
enterprises and non-state-owned enterprises, with 1 representing state-owned enterprises; 0 means non-state-owned enterprises; (4) Controlling variable is the shareholding ratio of the largest shareholder; (5) Dummy variables is annual and industry variables.

\section{Results and analysis}

\subsection{Descriptive statistics}

Table 1 reports the descriptive statistics. Of the 8600 samples, 3242 companies are over-investment, accounting for $37.7 \%$ of the total sample, and 5358 are underinvestment, accounting for $62.3 \%$ of the total sample. The average, minimum, and maximum values of over-investment are 0.050813, 4.82e-06, and 0.234941, respectively; the underinvestment values are 0.030746, 0.000346, and 0.104516, respectively. It can be seen the over-invested companies are far less than the under-invested ones, and the degree of under-investment is less than the degree of over-investment, and the inefficiency of investment is widespread in our listed companies. From the standard deviation of investment efficiency, the volatility between the indicators is large.

Table1. descriptive statistics.

\begin{tabular}{cccccc}
\hline variables & sample & average & sd & $\min$ & $\max$ \\
\hline$|\mathrm{UI}|$ & 8600 & 0.038311 & 0.034192 & $4.82 \mathrm{e}-06$ & 0.234941 \\
\hline $\mathrm{O}$ & 3242 & 0.050813 & 0.048526 & $4.82 \mathrm{e}-06$ & 0.234941 \\
\hline$|\mathrm{U}|$ & 5358 & 0.030746 & 0.017325 & 0.000346 & 0.104516 \\
\hline sar & 8600 & 0.647761 & 0.058285 & 0.001801 & 12.37286 \\
\hline roa & 8600 & 0.040223 & 0.167737 & -1.558383 & 10.03219 \\
\hline sh & 8600 & 34.46981 & 15.05355 & 0.29 & 89.99 \\
\hline
\end{tabular}

\subsection{Empirical test}

As is shown in Table 2 and Table 3, over-investment $\mathrm{O}$ and under-investment $\mathrm{U}$ are significantly positively correlated with accounting information quality EM, and their values are 0.0576* and $0.0617^{* *}$ respectively. It can be seen the improvement of the quality of accounting information can ease the inefficiency of investment; The information quality EM is positively related to the asset turnover rate of $U$ and $O$. The values are $-0.1113^{*}$ and 0.0071 , respectively. It can be seen the high-quality accounting information can speed up the turnover of the assets and thus improve the investment efficiency.

Table2. under-investment's pwccor coefficients.

\begin{tabular}{cccccc}
\hline variables & $|\mathrm{U}|$ & EM & sar & roa & sh \\
\hline$|\mathrm{U}|$ & 1.0000 & & & & \\
\hline $\mathrm{EM}$ & $0.0576^{*}$ & 1.0000 & & & \\
\hline sar & -0.0303 & $0.1113^{* *}$ & 1.0000 & & \\
\hline roa & $0.1242^{* *}$ & 0.0081 & $0.1590^{* *}$ & 1.0000 & \\
\hline sh & -0.0149 & $-0.0494^{*}$ & $0.0924^{* *}$ & $0.0703^{* *}$ & 1.0000 \\
\hline$* * *, * *, *$ & presents statistical significance at the $1 \%, 5 \%$ and $10 \%$ level, respectively.
\end{tabular}


Table3. over-investment's pwccor coefficients.

\begin{tabular}{|c|c|c|c|c|c|}
\hline variables & $\mathrm{O}$ & EM & sar & roa & sh \\
\hline $\mathrm{O}$ & 1.0000 & & & & \\
\hline EM & $0.0617^{* *}$ & 1.0000 & & & \\
\hline sar & $-0.0686^{* *}$ & 0.0071 & 1.0000 & & \\
\hline roa & $0.1191^{* *}$ & -0.0005 & $0.1521^{* *}$ & 1.0000 & \\
\hline sh & -0.0293 & -0.0280 & $0.0806^{* *}$ & $0.0797 * *$ & 1.0000 \\
\hline
\end{tabular}

As can be seen from Table 4, over-investment, under-investment and the quality of accounting information EM are positive relationships, and their values are 0.0594321 and 0.0168031 respectively. No matter whether the investment is over-invested or under-invested, the regression results with accounting information quality are significant. It can be seen the improvement of the quality of accounting information has an inhibitory effect on the inefficiency of corporate investment. However, the impact of accounting information quality on under-invested companies is significantly higher than that of over-invested companies. Hypothesis 1 is verified. The regression coefficients for overinvestment, underinvestment, and asset turnover were significantly negatively correlated at the $5 \%$ and $1 \%$ levels respectively; the regression coefficients for overinvestment, underinvestment, and return on assets were 0.13261 and 0.03907 , respectively, and were at the $1 \%$ level significantly. The higher the company's return on total assets, the lower the inefficiency of investment.

Table4.Accounting Information Quality and Investment efficiency regression Coe.

\begin{tabular}{ccc}
\hline variables & $\mathrm{O}$ & $|\mathrm{U}|$ \\
\hline EM & $0.0594321^{*}$ & $0.0168031^{* *}$ \\
& $(0.017)$ & $(0.000)$ \\
\hline sar & $-0.0057766^{*}$ & $-0.0031198^{* *}$ \\
& $(0.050)$ & $(0.000)$ \\
\hline roa & $0.1326054^{* *}$ & $0.0390763^{* *}$ \\
& $(0.000)$ & $(0.000)$ \\
\hline sh & -0.0000635 & -0.0000291 \\
& $(0.435)$ & $(0.119)$ \\
\hline cons & 0.0514894 & -0.0020489 \\
\hline R-square & 0.024 & 0.0323 \\
\hline p & 0.0000 & 0.0000 \\
\hline F & 5.60 & 15.12 \\
\hline year & yes & yes \\
\hline Ind & yes & yes \\
\hline$* * *, * *, *$ presents statistical significance at the $1 \%, 5 \%$ and $10 \%$ level, respectively.
\end{tabular}

\subsection{Extensibility test}

This section will add the nature of property rights as a control variable, and we will observe the degree of influence of the quality of accounting information and investment efficiency on different equity-type companies to verify whether Hypothesis 2 holds.

As can be seen from Table 5, the regression coefficient of non-efficient investment and accounting information quality of state-owned enterprises is 0.024212 , which is significantly correlated at the $1 \%$ level. The regression coefficients with the asset turnover rate and total assets return rate are all significantly related at the $1 \%$ level. The regression coefficient of non-state-owned enterprises' non-investment efficiency and accounting quality did not pass the test of significance. It can be seen the quality of accounting information of state-owned enterprises has a higher impact on 
investment efficiency than that of non-state-owned enterprises, which is totally opposite to the hypothesis. The reasons are probably the following two points: (1) The state's implementation of state-owned enterprises' policies and supervision are much stronger than the market's role, making the state-owned enterprises disclose high-quality accounting information to promote investment efficiency. For example, the continuous emphasis on anti-corruption efforts in recent years has forced state-owned enterprises to issue more transparent and fair financial information. (2) Among companies that meet the study conditions, the way to divide state-owned and non-state-owned companies is also one of the reasons.

Table5. The regression of property rights.

\begin{tabular}{ccc}
\hline variables & State-owned & Non-state-owned \\
\hline EM & $0.024212^{* *}$ & 0.0072393 \\
& $(0.009)$ & $(0.450)$ \\
\hline sar & $-0.0051906^{* *}$ & $-0.0033214^{*}$ \\
& $(0.000)$ & $(0.024)$ \\
\hline roa & $0.0589266^{* *}$ & $0.0339973^{* *}$ \\
& 0.000 & $(0.002)$ \\
\hline sh & -0.000102 & 0.0000235 \\
& $(0.779)$ & $(0.584)$ \\
\hline cons & 0.0359229 & 0.0387478 \\
\hline R-squared & 0.0203 & 0.020 \\
\hline year & yes & yes \\
\hline$* * * * *, *$ presents statistical significance at the $1 \%, 5 \%$ and $10 \%$ level, respectively.
\end{tabular}

\section{Conclusion}

The article chooses China's non-financial A-share listed companies between 2014 and 2016 to analyze the impact of the quality of accounting information on investment efficiency for the test sample. The study find that the quality of accounting information can significantly increase the efficiency of corporate investment. Further analysis shows that the quality of accounting information has a stronger effect in reducing investment insufficiency than suppressing the effects of excessive investment. Compared with non-state-owned enterprises, the relationship between accounting information quality and investment efficiency has a greater impact on state-owned enterprises.

\section{References}

[1] S.M. Chen, Z. Sun and S. Tang, Government Intervention and Investment Efficiency: Evidence from China[J]. Journal of Corporate Finance, vol.17, pp. 259-271,2011.

[2] R. Bushman and A. Smith, Financial accounting information and corporate governance[J]. Journal of Accounting and Economics, vol.32, pp.237-333,2001.

[3] R.C. Merton, Presidential Address: A Simple Model of Capital Market Equilibrium with Incomplete Information[J]. Journal of Finance, vol.42, pp. 483—510,1987.

[4] F. Chen, O.K. Hope and Q. Li, Financial reporting quality and investment efficiency of private firms in emerging markets[J]. The Accounting Review, vol.86, pp.1255—1288, 2011. 